\title{
AGRONOMIC CHARACTERISTICS OF MAIZE AFTER OVERLIMING
}

\author{
Fabrício Vilela Andrade Fiorini ${ }^{1 *}$, Lucas Leite Reis ${ }^{2}$, Adauton Vilela de Rezende ${ }^{1}$, Gian Otávio Alves da Silva ${ }^{1}$, \\ Raphaela Aparecida Tomaz do Prado ${ }^{1}$, Miguel Ribeiro Alves ${ }^{1}$ \\ 1 Departamento de Agronomia, Universidade José do Rosário Vellano- Unifenas, 37132-440, Alfenas, Brasil. \\ 2 Departamento de Produção Vegetal, Centro Superior de Ensino e Pesquisa de Machado- Cesep, 37750-000, Machado, Brasil.
}

*E-mail: fabriciovaf@hotmail.com

Recebido em: 30/11/2019

Aceito em: $28 / 07 / 2020$

\begin{abstract}
Overliming is an economical practice aimed at increasing cation exchange capacity (CEC) and soil base saturation (V \%), in addition to increasing grain and dry matter yield. The objective of this study was to evaluate the effects of overliming on the agronomic characteristics of maize. The experiment was carried out in a randomized block design (RBD), with four replications, where five treatments corresponded to the dosages $\left(1.9 ; 2.5 ; 3.2 ; 3.8\right.$ and $\left.4.4 \mathrm{t} \mathrm{ha}^{-1}\right)$ that simulated the increase in base saturation to $(60,70,80,90$ and 100\%), respectively. Plant height was evaluated, besides ear height, number of ears per plant, number of viable ears per plant, shoot fresh weight, root fresh weight, stem diameter, shoot dry matter, root dry matter, grain weight, weight of 100 grains, shoot dry weight and root dry weight. There was a significant variation for three of the evaluated characteristics and in the studied conditions, the overliming increased the such as shoot dry matter, root dry matter and shoot dry weight, emphasizing the dosages of $2.5 \mathrm{t} \mathrm{ha}^{-1}$ and $3.8 \mathrm{t} \mathrm{ha}^{-1}$ limestone.
\end{abstract}

Palavras-chave: Zea mays L. Limestone. Dry matter. Yield.

\section{Introduction}

The maize crop is of great importance for Brazilian agriculture, since it is used in animal feed as, both bulk and concentrate, and can be used to obtain silage, in addition to mixtures of concentrates for various animal species such as birds, cattle and pigs.

In the 2018/2019 crop season, the area planted with maize in Brazil was 17.07 million hectares, with a production of 92.81 million tons, which gives the country the third position in the ranking of the largest maize producers in the world, losing only to the United States and China [1].

For years, there has been an intense improvement in the maize crop, making it more responsive to increases in nutrients in the soil. Therefore, the liming process aids in the improvement in $\mathrm{pH}$ levels, increase in macronutrients calcium (Ca) and magnesium $(\mathrm{Mg})$, lower soil phosphorus $(\mathrm{P})$ fixation by the soil, increase in cation exchange capacity (CEC) and reduction in the toxic aluminum $(\mathrm{Al})$ in the soil [2].
It is important to emphasize that there is a relationship between soil $\mathrm{pH}$ and the availability of several essential plant nutrients, and the ideal $\mathrm{pH}$ is around 6.5 for most crops [3]. Since liming directly provides calcium and magnesium to the soil, the optimum proportion suggested for maize would be around 4:1, respectively, with aluminum being zeroed and CEC as high as possible [4].

Although several authors have found a positive relationship between liming and dry matter production of plant and grains, higher grain yield in maize, and significant increases in calcium and magnesium in leaf dry matter [5], overliming is sometimes dangerous, since it leads to a competition between the ions $\mathrm{Ca}$, $\mathrm{Mg}$ and potassium $(\mathrm{K})$ at the beginning of the plant cycle, thus resulting in a $\mathrm{K}$ deficiency, besides raising the $\mathrm{pH}$ above 6.5, which may result in the unavailability of the micronutrients $(\mathrm{Zn})$, copper $(\mathrm{Cu})$, manganese $(\mathrm{Mn})$, and iron $(\mathrm{Fe})[6]$.

Considering the above and the still existing inconsistencies on the overliming process in the maize crop, the objective of this study was to evaluate the effects of overliming on the agronomic characteristics of maize. The results of this study are important to 
clarify the consequences of the use of overliming, since this is an economical practice to increase cation exchange capacity (CEC) and soil base saturation (V\%), besides increasing grain and dry matter yield.

\section{Methodology}

The experiment was set and conducted at Centro Superior de Ensino e Pesquisa de Machado - Cesep, located in the city of Machado/MG, at an altitude of $863 \mathrm{~m}$ and geographic coordinates of $21^{\circ} 40^{\prime} 56^{\prime \prime} \mathrm{S}$ and $45^{\circ} 56^{\prime} 06^{\prime \prime} \mathrm{W}$ [7].

The experimental design was in randomized blocks (RBD), with four replicates and five treatments corresponding to the dosages $\left(1.9 ; 2.5 ; 3.2 ; 3.8\right.$ and 4.4 tons $\left.\mathrm{ha}^{-1}\right)$ that simulated the increase in base saturation to $(60,70,80,90$ and 100\%), respectively, with each plot consisting of only one maize plant per bag. A manually prepared substrate containing $720 \mathrm{~L}$ soil and $60 \mathrm{~kg}$ of bovine manure was used to fill the vessel-like bags.

After filling with approximately $36 \mathrm{~L}$ substrate in each bag, they were exposed to the sun and arranged in rows containing 5 units against each other, with a spacing of 0.70 meters between rows. Subsequently, the bags were cut about $5 \mathrm{~cm}$ above the substrate level, where a soil sample was taken to analyze the chemical composition (Table 1).

With the result of the soil analysis, limestone was added in the proportional amounts referred to above and incorporation was made with a knife at a depth of $20 \mathrm{~cm}$. The bags were then irrigated daily for the limestone reaction to occur. Thirty days after the application of limestone, in the second half of October, sowing was performed using the equivalent to $400 \mathrm{~kg} \mathrm{ha}^{-1}$ of Formulation $08(\mathrm{~N}): 28\left(\mathrm{P}_{2} \mathrm{O}_{5}\right): 16\left(\mathrm{~K}_{2} \mathrm{O}\right)+0.5 \% \mathrm{Zn}$ with incorporation into the substrate. Three seeds of the early-cyclesimple-hybrid AG 8061 PRO2 [8].were planted per bag, a semitoothed orange grain indicated for the production of grains and silage of high energy value, performing thinning at V2 stage (plant with 2 fully expanded leaves), leaving only one plant per pot.

After planting the seeds, irrigation was performed according to the daily requirement until reaching substrate field capacity in all plots and ceased when the grains reached the physiological maturity point. At V4 stage (plant with 4 fully expanded leaves), cover was performed with the incorporation of the equivalent of $350 \mathrm{~kg} \mathrm{ha}{ }^{-1}$ of the formulation $20(\mathrm{~N}): 00\left(\mathrm{P}_{2} \mathrm{O}_{5}\right): 20\left(\mathrm{~K}_{2} \mathrm{O}\right)$. Weeding was manual and there was no need to apply leaf fertilization, insecticides and fungicides in the crop.
Table 1 - Result of the substrate analysis used in the overliming experiment. CESEP, Machado/MG, 2019.

\begin{tabular}{|c|c|c|c|c|c|}
\hline \multirow[t]{2}{*}{ Sample } & $\mathbf{p H}$ & pH & $\begin{array}{c}\text { P } \\
\text { Mehlich }\end{array}$ & $\mathbf{K}^{+}$ & \multirow{2}{*}{$\begin{array}{c}\mathrm{Ca}^{2+} \\
\mathrm{cmolc}^{2+3}\end{array}$} \\
\hline & $\mathrm{Ca} \mathrm{Cl}_{2}$ & $\mathrm{H}_{2} \mathrm{O}$ & \multicolumn{2}{|c|}{$\mathrm{mg} \mathrm{dm}^{-3}$} & \\
\hline 01 & 4.7 & 5.3 & 4 & 98 & 1.1 \\
\hline \multirow[t]{2}{*}{ Sample } & $\mathrm{Mg}^{2+}$ & $\mathrm{Al}^{3+}$ & $\mathbf{H}+\mathbf{A l}$ & SB & $\mathbf{t}$ \\
\hline & \multicolumn{5}{|c|}{ cmolc dm $^{-3}$} \\
\hline 01 & 0.4 & 0 & 4.2 & 1.8 & 1.8 \\
\hline \multirow[t]{2}{*}{ Sample } & $\mathbf{T}$ & $\mathbf{V}$ & m & MO & P-rem \\
\hline & $\begin{array}{c}\text { (cmolc } \\
\left.\mathrm{dm}^{-3}\right)\end{array}$ & $\%$ & $\%$ & $\mathrm{~g} \mathrm{dm}^{-3}$ & $\mathrm{mg} \mathrm{L}^{-1}$ \\
\hline 01 & 6.0 & 30 & 0 & 15 & 12 \\
\hline
\end{tabular}

$\mathrm{pH}$ in calcium chloride $\left(\mathrm{CaCl}_{2}\right)$ and water $\left(\mathrm{H}_{2} \mathrm{O}\right)$; $\mathrm{P}$ (Mehlich Phosphorus); $\mathrm{K}^{+}$, $\mathrm{Ca}^{2+}, \mathrm{Mg}^{2+}$ and $\mathrm{Al}^{3+}$ (potassium, calcium, magnesium and aluminum), respectively; $\mathrm{H}+\mathrm{Al}$ (potential acidity); $\mathrm{SB}$ (base sum); $\mathrm{t}$ (effective cation exchange capacity); $\mathrm{T}$ (cation exchange capacity at $\mathrm{pH} 7,0$ ); $\mathrm{V}$ (base saturation); $\mathrm{m}$ (aluminum saturation); MO (organic matter) and P-rem (remaining phosphorus).

Source: Prepared by the authors.

Harvest was carried out in the second half of March, when the grains were already at physiological maturity (black layer). The following agronomic characteristics were evaluated: Plant height, ear height, number of ears per plant, number of viable ears per plant, shoot fresh weight, root fresh weight, stem diameter, shoot dry matter, root dry matter, grain weight, weight of 100 grains, shoot dry weight and root dry weight.

Plant height was measured with a scale, from the plant base at ground level to the insertion of the flag leaf; ear height was measured from the plant base at ground level to the insertion of the upper ear. The number of ears per plant was counted and, after dehusking, the viable ears were counted, that is, those that contributed to yield. Stem diameter was measured with a caliper in the center of the knot, just below the upper ear.

The weights were measured in a precision electronic scale, where moisture was corrected for grain weight and weight of 100 grains, after the grains were dried in the oven at $105^{\circ} \mathrm{C}$ for 24 hours. For correction of grain weight and weight of 100 grains, the following formula was used: Corrected weight $=(100-$ Initial moisture) x Initial weight/(100 - Storage moisture), where $13 \%$ was adopted as grain storage moisture.

In order to determine the total shoot and root dry matter, a sample of 100 grams was used, taken to an oven with air circulation at $55^{\circ} \mathrm{C}$ for 72 hours. After drying, a 3-g sample was obtained, taken to the oven with air circulation at $105^{\circ} \mathrm{C}$ for 12 
hours. Shoot and root dry weights of the plants were obtained after discarding all moisture, using total dry matter.

Data were submitted to the $\mathrm{F}$ test by analysis of variance (ANOVA). The Scott-Knott test at $\mathrm{p}<0.05$ was used to compare the means of each evaluated characteristic. The Sisvar software was used to analyze the data [9].

\section{Results and Discussion}

According to Table 2, there was no significant difference ( $p>0.05$ ) for the following evaluated agronomic characteristics: plant height, ear height, number of ears, viable ears, shoot fresh weight, root fresh weight and stem diameter. These values are considered normal, since only a simple hybrid (AG 8061 PRO2) was used with a great uniformity, thus not being influenced by the different liming levels.

Ribas et al. [10] studied the same hybrid (AG 8061 PRO2) cultivated in two planting spacings $(0.45$ and $0.90 \mathrm{~m})$, and found average plant height values equal to $2.30 \mathrm{~m}$, ear height equal to $1.32 \mathrm{~m}$ and stem diameter equal to $2.07 \mathrm{~cm}$, differing from the values found in this experiment, probably influenced by edaphoclimatic conditions and different spacings.

Carneiro et al. [6] evaluated the chemical attributes of a soil and found that overliming causes imbalance among soil nutrients, but that probably did not occur in this experiment, since there was no visual nutritional deficiency in the plants. The experiment also showed no attack of pests and diseases, dispensing the use of insecticides and fungicides. Therefore, the hybrid proved to be efficient in the resistance to insects and diseases present in the region where this study was conducted. The same authors found that overliming can increase base saturation, which raises soil $\mathrm{pH}$ to ranges where it causes low nutrient availability to plants.

Moreira, Fageria [11], Anjos et al. [12] and Marcelo et al. [13] studied doses up to 10.3, 9.5 and $3.6 \mathrm{t} \mathrm{ha}^{-1}$ limestone, respectively, and found a linear increase in soil $\mathrm{pH}$ as a function of liming with increasing doses and, in these studies, the $\mathrm{pH}$ did not exceed the range determined as ideal for crops (5.5 to 6.5). This was probably due to the greater buffering power of these soils.

According to Nduwumuremyi [14], liming aims to adjust soil acidity, raising $\mathrm{pH}$ and neutralizing toxic $\mathrm{Al}^{3+}$. Liming eliminates toxic $\mathrm{Al}^{3+}$ and $\mathrm{H}^{+}$through reactions with $\mathrm{OH}^{-}$. Excess $\mathrm{OH}^{-}$will raise soil $\mathrm{pH}$, which is the most recognizable effect of liming.

Regarding the agronomic characteristics shoot dry matter, root dry matter, grain weight, weight of 100 grains, shoot dry weight, root dry weight in Table 3 , there was a significant difference $(\mathrm{p}<0.05)$, varying the dry matter content of the shoot, root dry matter and shoot dry weight at the different dosages applied and, for the other characteristics, there was no statistical difference $(\mathrm{p}>0.05)$.

In general, shoot dry matter presented high values, due to the fact that the plants were harvested soon after the grains reached the physiological maturity point (black layer), values that resemble those of Vilela et al. [15] after harvesting four hybrids that had the grains in the black layer.

For shoot dry matter, the dosage of $2.5 \mathrm{t} \mathrm{ha}^{-1}$ limestone was higher than the others, showing a higher dry matter accumulation in the plant, also highlighting the dosage of $3.8 \mathrm{t} \mathrm{ha}^{-1}$ limestone, followed by the other treatments and where the smallest dry matter accumulation was found when $4.4 \mathrm{t} \mathrm{ha}^{-1}$ limestone was applied. According to Rodrigues et al. [16], with the application of overliming, there is an increase in $\mathrm{pH}$ and the availability of calcium $(\mathrm{Ca})$ and magnesium $(\mathrm{Mg})$, leading to a higher dry matter production in the maize plant.

Carmo, Silva [5] concluded that the electrical conductivity of the soil explains much of the variation maize dry and is positively related to nutrient concentration, which also predicts maize growth as a result of added carbonate levels, to the soil.

Carneiro et al. [6] found an increase of about $0.85 \mathrm{cmolc} \mathrm{dm}^{-3}$ per ton of $\mathrm{CaCO}_{3}$ applied to the soil; therefore, several studies, such as those by Marcelo et al. [13], with the application of up to $3.6 \mathrm{t} \mathrm{ha}^{-1}$; Araújo et al. [17], up to $6.9 \mathrm{t} \mathrm{ha}^{-1}$; Anjos et al. [12], with up to $9.5 \mathrm{t} \mathrm{ha}^{-1}$; and Moreira, Fageria [11], up to $10.3 \mathrm{t} \mathrm{ha}^{-1}$ of limestone, showed an increase in $\mathrm{Ca}^{2+}$ as a function of the application of limestone doses. The same authors observed that the phosphorus available in the soil showed a linear increase as a function of increasing calcium carbonate doses; this element is sensitive to soil $\mathrm{pH}$, and the production in soils with high acidity becomes a limiting factor. Increases in $\mathrm{pH}$ values from the use of correctives in agriculture are a practice that contributes to increase $\mathrm{P}$ availability and the efficiency of phosphate fertilizers [19].

Regarding root dry matter, the dosage of $3.8 \mathrm{t} \mathrm{ha}^{-1}$ limestone was higher than the others, with a higher dry matter accumulation in maize roots. Carmo, Silva [5] found that electrical conductivity increases due to increased liming levels, and there is a positive relationship between $\mathrm{Ca}^{2+}, \mathrm{Mg}^{2+}$, base saturation and $\mathrm{pH}$ levels for each particular soil class.

Regarding shoot dry weight, the most important dosages were $2.5 \mathrm{t} \mathrm{ha}^{-1}$ and $3.8 \mathrm{t} \mathrm{ha}^{-1}$ limestone, respectively, following the results of dry matter accumulation in the plant shoot. Probably, 
this higher dry matter accumulation should be related to the better use of $\mathrm{Ca}^{2+}$ and $\mathrm{Mg}^{2+}$ at the described dosages, being also verified by Andreotti et al. [4] in maize plants.

Other attributes that are modified after overliming are base sum (BS) and base saturation (V\%), and several studies show increased base saturation regardless of the management adopted [11-17-20].

The increase in V\% caused by overliming is mainly due to the reduction in potential acidity $(\mathrm{H}+\mathrm{Al})$ and the increase in $\mathrm{Ca}^{2+}$ levels, a result also observed by Calonego et al. [21]. Nduwumuremyi [14] states that the relatively high V\% should be maintained for most cropping systems, as this saturation determines base availability for plant uptake and strongly influences soil $\mathrm{pH}$.

Although there was no significant difference for the characteristics grain weight and weight of 100 grains, the values suggest that the size of the experimental plot should be increased and should be observed in plots with double rows of four or five meters long, or even in commercial plantations with strip treatments.

For Carneiro et al. [6], studies on the evaluation of the effect of overliming on soil fertility, especially in the Cerrado, are uncommon. However, with the advance of no-tillage cultivation and management frequently performed incorrectly, the effect of overliming needs to be addressed. studied under these conditions, as well as its effects on nutrient availability, especially micronutrients. Silva et al. [22] concluded that excessive liming is less harmful to plants than not performing it, even if not recommended.

Further studies on overliming are necessary, as it may become a favorable and cost-effective practice to increase cation exchange capacity (CEC) and soil base saturation (V\%), increase dry matter and grain yield.

Table 2 - Agronomic characteristics obtained in the overliming experiment; Plant height (PH) and ear height (EH) in meters; Number of ears (NE), Viable ears (VE), Shoot fresh weight (SFW), Root fresh weight (RFW) in grams and stem diameter (SD) in centimeters. CESEP, Machado/MG, 2019.

\begin{tabular}{|c|c|c|c|c|c|c|c|}
\hline \multirow{2}{*}{$\begin{array}{c}\text { Limestone doses } \\
\left(\mathrm{t} \mathrm{ha}^{-1}\right)\end{array}$} & \multicolumn{7}{|c|}{ Agronomic characteristics } \\
\hline & PH & EH & NE & VE & SFW & RFW & SD \\
\hline 1,9 & $2.57 \mathrm{a}$ & $1.23 \mathrm{a}$ & $3.50 \mathrm{a}$ & $3.25 \mathrm{a}$ & $862.50 \mathrm{a}$ & $561.25 \mathrm{a}$ & $3.25 \mathrm{a}$ \\
\hline 2,5 & $2.55 \mathrm{a}$ & $1.24 \mathrm{a}$ & $3.25 \mathrm{a}$ & $3.00 \mathrm{a}$ & $928.75 \mathrm{a}$ & $766.25 \mathrm{a}$ & $3.28 \mathrm{a}$ \\
\hline 3,2 & $2.54 \mathrm{a}$ & $1.12 \mathrm{a}$ & $3.50 \mathrm{a}$ & $2.75 \mathrm{a}$ & $762.50 \mathrm{a}$ & $667.50 \mathrm{a}$ & $3.08 \mathrm{a}$ \\
\hline 3,8 & $2.54 \mathrm{a}$ & $1.15 \mathrm{a}$ & $3.00 \mathrm{a}$ & $2.75 \mathrm{a}$ & $857.50 \mathrm{a}$ & $767.50 \mathrm{a}$ & $3.08 \mathrm{a}$ \\
\hline 4,4 & $2.58 \mathrm{a}$ & $1.19 \mathrm{a}$ & $3.25 \mathrm{a}$ & $3.25 \mathrm{a}$ & $807.50 \mathrm{a}$ & $800.00 \mathrm{a}$ & $3.28 \mathrm{a}$ \\
\hline Mean & 2.56 & 1.19 & 3.30 & 3.00 & 843.75 & 712.50 & 3.19 \\
\hline CV\% & 5.85 & 6.87 & 18.56 & 24.13 & 16.82 & 29.35 & 7.02 \\
\hline
\end{tabular}

Means followed by the same lowercase letters in the column belong to the same grouping, by the Scott Knott test at 5\% probability. CV\% (coefficient of variation in percentage).

Source: Prepared by the authors. 
Table 3 - Agronomic characteristics obtained in the overliming experiment; shoot dry matter (SDM), root dry matter (RDM), grain weight (GW), weight of 100 grains (W100g), shoot dry weight (SDW), rooto dry weight (RDW), in grams. CESEP, Machado/MG, 2019.

\begin{tabular}{|c|c|c|c|c|c|c|}
\hline \multirow{2}{*}{$\begin{array}{c}\text { Limestone } \\
\left(\mathrm{t} \mathrm{ha}^{-1}\right)\end{array}$} & \multicolumn{6}{|c|}{ Agronomic characteristics } \\
\hline & SDM & RDM & GW & W100G & SDW & RDW \\
\hline 1.9 & $42.91 \mathrm{c}$ & $22.62 \mathrm{c}$ & $519.28 \mathrm{a}$ & $43.86 \mathrm{a}$ & $370.00 \mathrm{~b}$ & $126.50 \mathrm{a}$ \\
\hline 2.5 & $55.39 \mathrm{a}$ & $27.47 \mathrm{~b}$ & $401.10 \mathrm{a}$ & $40.93 \mathrm{a}$ & $514.00 \mathrm{a}$ & $212.25 \mathrm{a}$ \\
\hline 3.2 & $43.70 \mathrm{c}$ & $26.17 b$ & $346.71 \mathrm{a}$ & $37.96 \mathrm{a}$ & $332.75 \mathrm{~b}$ & $174.50 \mathrm{a}$ \\
\hline 3.8 & $49.40 \mathrm{~b}$ & $30.18 \mathrm{a}$ & $406.81 \mathrm{a}$ & $41.27 \mathrm{a}$ & $423.50 \mathrm{a}$ & $231.50 \mathrm{a}$ \\
\hline 4.4 & $41.61 \mathrm{~d}$ & $27.74 \mathrm{~b}$ & $465.80 \mathrm{a}$ & $42.54 \mathrm{a}$ & $334.75 \mathrm{~b}$ & $221.75 \mathrm{a}$ \\
\hline Mean & 46.60 & 26.84 & 427.94 & 41.31 & 395.00 & $\begin{array}{l}193.30 \\
\end{array}$ \\
\hline CV \% & 1.59 & 3.43 & 22.94 & 8.49 & 17.13 & 29.76 \\
\hline
\end{tabular}

Means followed by the same lowercase letters in the column belong to the same grouping, by the Scott Knott test at 5\% probability. CV\% (coefficient of variation in percentage).

Source: Prepared by the authors.

\section{Conclusion}

Under the studied conditions, overliming increased some agronomic characteristics of maize, such as shoot dry matter, root dry matter and shoot dry weight, emphasizing the dosages of 2.5 $\mathrm{t} \mathrm{ha}^{-1}$ and $3.8 \mathrm{t} \mathrm{ha}^{-1}$ limestone.

\section{Acknowledgements}

The Higher Education Personnel Improvement Commission (CAPES) for granting scholarships to three of the authors.

\section{CARACTERÍSTICAS AGRONÔMICAS DO MILHO APÓS SUPERCALAGEM}

RESUMO: A supercalagem é uma prática econômica para se elevar a capacidade de troca de cátions (CTC) e saturação por bases do solo (V\%), além de aumentar a produtividade de grãos e matéria seca. Objetivou-se com esse trabalho avaliar os efeitos da supercalagem nas características agronômicas do milho. O experimento foi realizado em delineamento de blocos casualizados (DBC), com quatro repetições, onde cinco tratamentos correspondem às dosagens $(1,9 ; 2,5 ; 3,2 ; 3,8$ e 4,4 toneladas ha-1) que simularam a elevação da saturação por bases para $(60,70,80,90$ e 100\%), respectivamente. Avaliou-se altura de plantas, altura de espigas, número de espigas por planta, número de espigas viáveis por planta, peso fresco da parte aérea, peso fresco das raízes, diâmetro de colmo, matéria seca da parte aérea, matéria seca das raízes, peso de grãos, peso de 100 grãos, peso seco da parte aérea e peso seco das raízes. Houve variação significativa para três das características avaliadas e nas condições estudadas, a supercalagem aumentou a matéria seca da parte aérea, matéria seca das raízes e peso seco da parte aérea, com destaque para as dosagens de 2,5 t ha- 1 e 3,8 t ha- 1 de calcário.

Palavras-chave: Zea mays L. Calcário. Matéria seca. Produtividade.

\section{References}

[1] CONAB- Acompanhamento da safra brasileira de grãos 2018/2019 (2019). Disponível em file:///C:/Users/cliente/Downloads/GraosZmarcoZ2019_completo\%20(2).pdf Acesso em: 18 abril de 2019.

[2] RAIJ, B. V. Fertilidade do solo e manejo de nutrientes. Piracicaba: IPNI, 2011. 420p

[3] MALAVOlTA, E.; VITTI, G. C.; OLIVEIRA, A. S. Avaliação do estado nutricional das plantas: princípios e aplicações. Piracicaba: Associação Brasileira para Pesquisa da Potassa e do Fosfato, 1989. 201 p.

[4] ANDREOTTI, M.; SOUZA, E. C. A.; CRUSCIOL, C. A. C. Componentes morfológicos e produção de matéria seca de milho em função da aplicação de calcário e zinco. Scientia agrícola, v.58, p. 321-327, 2001.

[5] CARMO, D. L.; SILVA, C. A. Condutividade elétrica e crescimento do milho em solos contrastantes sob aplicação de diversos níveis de calagem. Pesquisa Agropecuária Brasileira, v.51, p. 1762-1772, 2016.

[6] CARNEIRO, J. S. S.; SOUSA, S. A.; NIKKEL, M.; DEUSDARÁ, T. T.; MACHADO, A. F.; SILVA, R. R. Supercalagem: alterações em atributos químicos de um latossolo vermelho-amarelo distrófico. Revista de Ciências Agroambientais, v. 16, p. 31-38, 2018. DOI: 10.5327/Z1677-606220181522

[7]GOOGLE EARTH- Mapas (2019) Disponível em: https://www.google.com.br/intl/pt-BR/earth/. Acesso em: 18 abril de 2019.

[8]SEMENTES AGROCERES. Disponível em: http://www.sementesagroceres.com.br/pages/Home.aspx. Acessado em: 18 abril de 2019. 
[9] FERREIRA, D. F. Sisvar: a computer statistical analysis system. Ciência e Agrotecnologia, v. 35, p. 1039-1042, 2011.

[10] RIBAS, M. R.; TAVARES, C. J.; REZENDE, B. P. M.; CUNHA, P. C. R.; JAKELAITIS, A. Competição de híbridos de milho com plantas daninhas em dois espaçamentos entrelinhas, v. 6, p. 02-05, 2013.

[11] MOREIRA, A.; FAGERIA, N. K. Liming influence on soil chemical properties, nutritional status and yield of alfalfa grown in acid soil. Revista Brasileira de Ciência do Solo, v. 34, p. 1231-1239, 2010.

[12] ANJOS, J. L.; SOBRAL, L. F.; LIMA JUNIOR, M. A. Efeito da calagem em atributos químicos do solo e na produção da laranjeira. Revista Brasileira de Engenharia Agrícola e Ambiental, v.15, p. 1138-1142, 2011.

[13] MARCELO, A. V.; CORÁ, J. E.; SCALA JUNIOR, N. L. Influence of liming on residual soil respiration and chemical properties in a tropical no-tillage system. Revista Brasileira de Ciência do Solo, v. 36, p. 45-50, 2012.

[14] NDUWUMUREMYI, A. Soil acidification and lime quality: sources of soil acidity, its effects on plant nutrients, efficiency of lime and liming requirements. Journal of Agriculture and Allied Sciences, v. 2, p.26-34, 2013.

[15] VILELA, H. H.; REZENDE, A. V.; VIEIRA, P. F.; ANDRADE, G; A.; EVANGELISTA, A. R.; ALMEIDA, G. B. S. Valor nutritivo de silagens de milho colhido em diversos estádios de maturação. Revista Brasileira de Zootecnia, v.37,p. 1192-1199. 2008.

[16] RODRIGUES, M.; SILVEIRA, C. A. P.; VAHL, L. C. Efeito da aplicação de calcário e subproduto da exploração de calcário sobre $\mathrm{pH}, \mathrm{Ca}$ e $\mathrm{Mg}$ do solo e na produção de massa seca do milho. In: III Congresso Brasileiro de Rochagem, Pelotas, Anais, Embrapa Clima Temperado, 455 p. 2017.

[17] ARAÚJO, S. R.; DEMATTÊ, J. A. M.; GARBUIO, F. J. Aplicação de calcário com diferentes graus de reatividade: alterações químicas no solo cultivado com milho. Revista Brasileira de Ciência do Solo, v. 33, p. 1755-1764, 2009.

[18] VILELA, H. H.; REZENDE, A. V.; VIEIRA, P. F.; ANDRADE, G; A.; EVANGELISTA, A. R.; ALMEIDA, G. B. S. Valor nutritivo de silagens de milho colhido em diversos estádios de maturação. Revista Brasileira de Zootecnia, v.37,p. 1192-1199. 2008.

[19] ARRUDA, E. M.; LANA, R. M. Q.; PEREIRA, H. S. Fósforo extraído por mehlich $^{-1}$ e resina de troca aniônica em solos submetidos à calagem. Bioscience Journal, v. 31, p.1107-1117, 2015.

[20] ROSSATO, O. B.; CERETTA, C. A.; SILVA, L. S.; BRUNETTO, G.; ADORNA, J. C.; GIROTTO, E.; LORENZI, C. R. Correction of soil acidity in the subsurface of an oxisol with sandy loam texture under no-tillage. Revista Brasileira de Ciência do Solo, v. 33, p.659-667, 2009.

[21] CALONEGO, J. C.; GIL, F.C; ROCCO, V. F.; SANTOS, E. A. Persistência e liberação de nutrientes da palha de milho,braquiária e labe-labe. Bioscience Journal, v. 28, p.770-781, 2012

[22] SILVA, W. B.; BARCELOS, F. P.; SICHOCKI, D.; SILVA, G. M. C. Uso do silicato de cálcio na correção da acidez do solo e no desenvolvimento da Brachiaria ruziziensis L. Perspectivas: Ciências Exatas \& Engenharia, v. 4, p. 1$11,2014$. 